\title{
ANALISIS HUBUNGAN BEBAN KERJA MENTAL DENGAN STRES KERJA
}

\author{
Dikky Fahamsyah \\ Persatuan Alumni Kesehatan Masyarakat Indonesia \\ Provinsi Jawa Timur, Indonesia \\ Email: diky.fahamsyah27@gmail.com
}

\begin{abstract}
Mental workload is a workload which is the difference between the demands of the workload of a task with a maximum capacity load of a person's mental condition motivated, excessive workload will lead to the incident of stress. Work stress is distress experienced by employees when facing job. The purpose of this research was to study the picture of mental workload and stress on employees who work in CSSD Installation General Hospital Haji Surabaya. This research was a descriptive cross sectional approach. The subjects of this research were employees in the Installation CSSD General Hospital Haji Surabaya. The variables of this research were the mental workload and job stress. Primary data was collected using questionnaires and observation. Secondary data obtained from the General Hospital Haji Surabaya. Furthermore the data was processed by descriptive and described in narrative form. The results showed that the CSSD employees experiencing mental workload which was divided into seven employees experiencing medium metal workload and four employees experiencing low mental workload. In addition there was a relationship between mental workload with the incidence of workplace stress. overall it can be described that mental workload and workplace stress were in the medium level. It was recommended that employees can used the time off well and getting used to exercise to increase endurance.
\end{abstract}

Keywords: mental workload, Job stress

\begin{abstract}
ABSTRAK
Beban kerja mental adalah beban kerja yang merupakan selisih antara tuntutan beban kerja dari suatu tugas dengan kapasitas maksimum beban mental seseorang dalam kondisi termotivasi, beban kerja yang berlebihan akan mengakibatkan adanya kejadian stres. Stres kerja adalah perasaan tertekan yang dialami karyawan dalam menghadapi pekerjaannya. Tujuan dari penelitian ini adalah untuk mempelajari gambaran beban kerja mental dan stres kerja pada karyawan di Instalasi CSSD Rumah Sakit Umum Haji Surabaya. Penelitian ini adalah penelitian deskriptif dengan pendekatan cross sectional. Subjek dari penelitian ini adalah karyawan di Instalasi CSSD Rumah Sakit Umum Haji Surabaya. Variabel dari penelitian ini adalah beban kerja mental dan stres kerja. Data primer diperoleh dengan menggunakan kuesioner dan observasi. Data sekunder diperoleh dari Rumah Sakit Umum Haji Surabaya. Selanjutnya data tersebut diolah secara deskriptif dan dijelaskan dalam bentuk narasi. Hasil penelitian menunjukkan bahwa karyawan di CSSD mengalami beban kerja mental yang dibagi menjadi beban kerja sedang sebanyak 7 orang dan 4 orang yang mengalami beban kerja mental rendah. Selain itu terdapat hubungan antara beban kerja mental dengan kejadian stres kerja. Tercatat karyawan yang mengalami stres kerja sedang sebanyak 6 orang dan 5 orang mengalami stres kerja rendah. Secara keseluruhan gambaran kejadian beban kerja mental dan stres kerja berada pada kondisi sedang. Disarankan agar Karyawan memanfaatkan waktu istirahat dengan baik dan membiasakan berolahraga untuk meningkatkan daya tahan tubuh.
\end{abstract}

Kata kunci: beban kerja mental, stres kerja

\section{PENDAHULUAN}

Kesehatan kerja merupakan sebuah kondisi dimana hal tersebut bebas dari gangguan rasa sakit baik fisik ataupun mental yang disebabkan oleh lingkungan kerja. Risiko kesehatan yang ditimbulkan dalam periode waktu tertentu dapat menyebabkan stres, emosi atau gangguan fisik (Mangkunegara, 2011). Kesehatan kerja harus diterapkan di tempat kerja pada jabatan apapun yang dilakukan dengan sebaik-baiknya. (Harrington \& Gill, 2005).

Rumah Sakit merupakan tempat kerja yang mengadakan pelayanan kesehatan perorangan secara paripurna yang menyediakan pelayanan rawat inap, rawat jalan, dan gawat darurat. Salah satu upaya penyelenggaraan kesehatan yang paripurna, Rumah Sakit harus dapat mengatasi ancaman infeksi yang 
disebabkan oleh mikroorganisme patogen. Proses sterilisasi adalah hal yang paling utama dalam menentukan steril atau tidaknya dari sediaan akhir bahan dan peralatan. Perlu dilaksanakan proses sterilisasi yang sesuai dan tepat dengan kategori sifat masing-masing bahan, alat serta wadah yang akan digunakan. Kegiatan ini dilaksanakan pada Instalasi Central Steril Supply Department (CSSD). (UndangUndang Republik Indonesia No. 44 tahun 2009).

Sterilisasi sentral di Rumah Sakit meliputi kegiatan sterilisasi, desinfeksi, dan pembersihan sebelum semua instrument, bahan dan peralatan dipakai untuk perawatan pasien. Barang-barang medis kotor dari berbagai ruangan di Rumah Sakit seperti ruang rawat inap, ruang rawat jalan, ruang operasi, dan ruang-ruang lainnya dikumpulkan di CSSD untuk diproses, kemudian diangkut kembali dalam keadaan steril. Semua kegiatan proses pembersihan, disinfeksi, pengemasan, sterilisasi, penyimpanan dan pendistribusiannya dilakukan oleh petugas khusus yang terlatih. Kegiatan ini untuk memastikan kontrol yang lebih baik dan hasil yang dapat diandalkan serta berkurangnya risiko akibat infeksi. (Kemenkes RI, 2012).

Salah satu institusi penyedia pelayanan kesehatan adalah Rumah Sakit dan penilaian terhadap suatu keberhasilan di Rumah Sakit dapat dilihat dari rendahnya angka infeksi nosokomial yang merupakan suatu indikator penilaian. Maka dari itu Rumah Sakit melakukan upaya pengendalian infeksi untuk mencapai keberhasilan tersebut. Hambatan yang ada dapat menyebabkan terganggunya proses dan hasil sterilisasi. Berdasarkan hasil survei awal yang dilakukan di Rumah Sakit Haji pada bagian Instalasi CSSD didapatkan bahwa jumlah karyawan yang ada pada bagian Instalasi kurang dari jumlah yang telah ditetapkan berdasarkan penghitungan beban kerja seharusnya yang berjumlah 18 karyawan serta beberapa alat sterilisasi sedang proses maintenance. Data kunjungan pasien Rumah Sakit Umum Haji Surabaya mengalami peningkatan pada tiga tahun terakhir yang memiliki arti bahwa semakin banyak kunjungan pasien maka proses pelayanan yang diberikan juga akan meningkat. Dari hasil wawancara dengan karyawan dikatakan bahwa adanya komplain dari beberapa ruangan terkait dengan proses kedatangan alat yang telah di sterilisasi dari Instalasi CSSD. Dari data hasil wawancara dan survei awal yang didapatkan maka peneliti ingin membahas tentang beban kerja mental dan kejadian stres kerja yang dialami oleh karyawan di Instalasi CSSD Rumah Sakit Umum Haji Surabaya.

Tujuan dari penelitian ini secara umum untuk mempelajari gambaran hubungan beban kerja mental dengan stres kerja pada karyawan di Instalasi CSSD Rumah Sakit Umum Haji Surabaya. Secara khusus yaitu untuk mempelajari tentang gambaran beban kerja mental yang dialami oleh tenaga kerja juga serta gambaran terhadap kejadian stres dari karyawan di Instalasi CSSD Rumah Sakit Umum Haji Surabaya.

\section{METODE}

Jenis penelitian ini adalah penelitian observasional dengan metode wawancara menggunakan kuesioner yang dilakukan pada bagian Instalasi CSSD di Rumah Sakit Umum Haji Surabaya. Penelitian ini dilakukan pada bulan November sampai dengan Desember 2016. Penelitian ini merupakan penelitian secara observasional sehingga data yang telah terkumpulkan dan akan dianalisis secara deskriptif yang penyampaian data dilakukan dalam bentuk narasi.

Metode penelitian yang digunakan selama penelitian berlangsung adalah observasi lapangan, yang dilakukan untuk mengamati kondisi pada Instalasi CSSD dan pengumpulan data dilakukan menggunakan kuesioner yang di berikan pada karyawan di Instalasi CSSD Rumah Sakit Umum Haji Surabaya. Penelitian ini menggunakan Rancangan cross sectional study yang dilaksanakan pada bulan November sampai Desember. Data primer didapatkan dengan cara observasi dan pengisian kuesioner. Sedangkan, data sekunder didapatkan dari Rumah Sakit Umum Haji Surabaya.

Sasaran dari penelitian ini adalah semua karyawan yang berada di Instalasi CSSD Rumah Sakit Umum Haji Surabaya. Proses pengumpulan data dilakukan menggunakan kuesioner NASA-TLX yang akan diisi oleh semua karyawan dan semua karyawan akan diberikan penjelasan tentang tata cara pengisian kuesioner serta melakukan penanda tanganan informed consent. Metode yang digunakan pada penelitian ini adalah Penilaian Beban Kerja dengan menggunakan Metode National Aeronautics \& Space Administration-NASA (Task Load Index$T L X)$. Langkah-langkah pengukuran dengan menggunakan NASA TLX adalah sebagai berikut Meshkati (1988) dalam Tarwaka (2010): 


\section{Pembobotan}

Pada bagian pembobotan, tenaga kerja diminta untuk memilih salah satu dari dua dimensi yang dibandingkan. Total perbandingan berpasangan untuk keseluruhan dimensi (6 dimensi) yaitu berjumlah 15 pilihan pasangan. Jumlah perhitungan untuk masing-masing dimensi inilah yang akan menjadi bobot dimensi.

\section{Pemberian Rating}

Pada bagian rating, responden diminta memberikan penilaian/rating terhadap keenam dimensi beban kerja mental dalam skala 0-100 sesuai dengan beban kerja yang dirasakan. Melakukan penjumlahan skor total setelah proses pengisian kuesioner untuk mendapatkan total skor beban kerja mental NASA-TLX, bobot dan rating untuk setiap indikator dikalikan kemudian dijumlahkan dan dibagi 15, hasil total kuesioner tersebut dibandingkan dengan standar yang digunakan apabila hasil skor $>80$ maka beban kerja mental yang dialami karyawan berada pada tingkatan beban berat, skor 50-80 beban sedang, dan $<50$ beban kerja ringan.

Metode pengumpulan data stres kerja karyawan di Instalasi CSSD Rumah Sakit Umum Haji Surabaya dilakukan dengan metode Self Report Measure. Teknik ini dinamakan life event scale. Stres diukur dengan melalui kuesioner yang berisikan tentang intensitas pengalaman psikologis, fisiologis dan perubahan fisik yang dialami dalam peristiwa kehidupan seseorang. Self report measure ini yang paling sering digunakan dalam penelitian. Hal ini dikarenakan live event scale dianggap manageable dan relatif lebih mudah. Tenaga kerja akan mengisi kuesioner dengan skala likert yang terdiri dari 35 daftar pertanyaan yang jawaban skoring-nya dimulai dari tidak pernah sampai dengan selalu.

Proses pengolahan data dilakukan dengan cara deskriptif yang disajikan dalam bentuk narasi untuk menggambarkan kondisi dari variabel-variabel yang telah diteliti yaitu mulai dari variabel beban kerja mental dan variabel stres kerja serta hubungan dari kedua variabel tersebut.

\section{HASIL}

\section{Gambaran Umum Rumah Sakit Haji Surabaya}

Rumah Sakit Umum (RSU) Haji Surabaya adalah Rumah Sakit milik Provinsi Jawa Timur, didirikan berkenaan dengan peristiwa yang menimpa para jama'ah haji Indonesia di terowongan Mina pada tahun 1990. Adanya bantuan dana dari pemerintah Arab Saudi dan dilanjutkan dengan biaya dari Pemerintah Provinsi Jawa Timur, berhasil dibangun gedung beserta fasilitasnya yang resmi dibuka pada 17 April 1993 sebagai Rumah Sakit Umum Kelas C oleh Almarhum Presiden Soeharto dan berdasarkan Perda No. 23 Tahun 2002 sebagai Rumah Sakit Umum Kelas B Non Pendidikan. Saat ini status RSU Haji Surabaya berdasarkan SK Menkes No. 1003/ MENKES/SK/X/2008 pada tanggal 30 Oktober 2008 telah menjadi Rumah Sakit Umum Kelas B Pendidikan dan bertanggung jawab langsung melalui Sekretaris Daerah Provinsi Jawa Timur kepada Gubernur.

Rumah Sakit Umum Haji Surabaya memiliki 226 tempat tidur perawatan dan akan bertambah seiring dengan pembangunan gedung baru yang sedang dalam tahap pengerjaan serta ditunjang alat medis canggih dan dokter spesialis di Surabaya yang melayani seluruh lapisan masyarakat umum. RSU Haji memperoleh Sertifikat ISO 9001: 2000 pada tahun 2008 untuk Paviliun Graha Nuur Afiyah dan Instalasi Gawat Darurat. Pada tahun 2010, RSU Haji Surabaya kembali memperoleh pengakuan standar mutu yakni Sertifikat ISO 9001:2008 dan berdasarkan standar internasional oleh National Quality Assurance (NQA) Indonesia untuk ruang lingkup: provision of outpatient, inpatient, emergency care, operating theatre, and hospital supporting service activities integrated with clinical governance and patient safety.

Pusat sterilisasi dan pencucian merupakan instalasi di Rumah Sakit Umum Haji Surabaya yang mempunyai ruang lingkup dalam memberikan pelayanan semua unit Rumah Sakit meliputi:

Pelayanan sentral sterilisasi memberikan pelayanan dan membantu semua unit di Rumah Sakit yang membutuhkan barang dan alat medis dalam kondisi steril, untuk mencegah terjadinya infeksi. Proses pelayanan penyediaan barang steril dimulai dari: penerimaan, pengemasan, labeling, proses sterilisasi, penyimpanan dan penyerahan barang dan alat medis steril.

Pelayanan pencucian memberikan pelayanan yang sebaik-baiknya untuk melayani dan membantu semua unit di Rumah Sakit yang membutuhkan ketersediaan linen yang bersih, aman, siap pakai. Proses pelayanan penyediaan linen bersih siap pakai dimulai dari: penerimaan linen kotor, pemilahan, perendaman, proses pencucian, pengeringan, penyetrikaan, pengemasan dan penyerahan linen yang bersih, aman dan siap pakai. 
Tabel 1. Distribusi Kelompok Umur pada Tenaga Kerja Instalasi CSSD Rumah Sakit Umum Haji Surabaya

\begin{tabular}{lcc}
\hline Kelompok Umur & Frekuensi (n) & Persentase (\%) \\
\hline 25-29 tahun & 1 & 9,091 \\
30-34 tahun & 1 & 9,091 \\
35-39 tahun & 1 & 9,091 \\
40-44 tahun & 4 & 36,364 \\
45-49 tahun & 3 & 27,273 \\
50-54 tahun & 1 & 9,091 \\
\hline Total & 11 & 100 \\
\hline
\end{tabular}

Tabel 2. Distribusi Tingkat Pendidikan pada Tenaga Kerja Instalasi CSSD Rumah Sakit Umum Haji Surabaya

\begin{tabular}{lcc}
\hline $\begin{array}{c}\text { Tingkat } \\
\text { Pendidikan }\end{array}$ & Frekuensi (n) & Persentase (\%) \\
\hline SLTP & 1 & 9,091 \\
SMA/SMK & 6 & 54,545 \\
D3 & 2 & 18,182 \\
S1 & 2 & 18,182 \\
\hline Total & 11 & 100 \\
\hline
\end{tabular}

Instalasi pusat sterilisasi dan pencucian merupakan unit pelaksana fungsional di Rumah Sakit, yang memiliki tugas pokok dalam pelaksanaan upaya pelayanan sterilisasi dan pencucian yang bermutu dengan mengutamakan kebutuhan unit-unit yang dilayani sebagai upaya untuk meningkatkan pelayanan kepada pasien. Instalasi CSSD ini merupakan salah satu mata rantai yang sangat penting dalam upaya pengendalian infeksi dan berperan dalam menekan kejadian infeksi di Rumah Sakit Umum Haji Surabaya.

\section{Distribusi Frekuensi Kelompok Umur}

Hasil penelitian karakteristik tenaga kerja tentang distribusi frekuensi kelompok umur di bagian Instalasi CSSD Rumah Sakit Umum Haji Surabaya ditampilkan pada Tabel 1.

Hasil Tabel 1 menunjukkan bahwa ada 6 kelompok umur dari tenaga kerja di Instalasi CSSD dimulai dari kelompok umur 25-29 tahun sampai dengan kelompok umur 50-54 tahun. Sedangkan, hasil penelitian didapatkan bahwa umur tenaga kerja berkisar antara 28 tahun hingga 52 tahun. Tenaga kerja di Instalasi CSSD terbanyak berada pada kelompok berumur 40-44 tahun sebanyak 4 orang $(36,3 \%)$.
Tabel 3. Distribusi Masa Kerja pada Tenaga Kerja Instalasi CSSD Rumah Sakit Umum Haji Surabaya

\begin{tabular}{lcc}
\hline \multicolumn{1}{c}{ Masa kerja } & Frekuensi (n) & Persentase(\%) \\
\hline$<10$ tahun & 2 & 18,182 \\
$>10$ tahun & 9 & 81,818 \\
\hline Total & 11 & 100 \\
\hline
\end{tabular}

Tabel 4. Distribusi Beban Kerja Mental pada Tenaga Kerja Instalasi CSSD Rumah Sakit Umum Haji Surabaya

\begin{tabular}{lcc}
\hline $\begin{array}{c}\text { Beban Kerja } \\
\text { Mental }\end{array}$ & $\begin{array}{c}\text { Frekuensi } \\
(\mathbf{n})\end{array}$ & $\begin{array}{c}\text { Persentase } \\
(\mathbf{\%})\end{array}$ \\
\hline Ringan & 4 & 36,364 \\
Sedang & 7 & 63,636 \\
\hline Total & 11 & 100 \\
\hline
\end{tabular}

\section{Distribusi Frekuensi Tingkat Pendidikan}

Hasil penelitian karakteristik tenaga kerja tentang distribusi frekuensi tingkat pendidikan di bagian Instalasi CSSD Rumah Sakit Umum Haji Surabaya ditampilkan pada tabel 2.

Tenaga kerja di Instalasi CSSD memiliki latar belakang pendidikan yang berbeda mulai dari tingkat SLTP sampai dengan pendidikan sarjana. Sedangkan dari hasil kuesioner tenaga kerja Instalasi CSSD paling banyak pada tingkatan SMA dan Sederajat sebanyak 6 orang $(54,5 \%)$.

\section{Distribusi Frekuensi Masa Kerja}

Hasil penelitian karakteristik tenaga kerja tentang distribusi frekuensi masa kerja di bagian Instalasi CSSD Rumah Sakit Umum Haji Surabaya ditampilkan pada Tabel 3.

Hasil penelitian dari Tabel 3 menunjukkan bahwa tenaga kerja di instalasi CSSD Rumah Sakit Umum Haji Surabaya memiliki masa kerja kurang dari 10 tahun dan lebih dari 10 tahun. Dari 11 tenaga kerja sebagian besar telah memiliki masa kerja lebih dari 10 tahun yang berjumlah 9 tenaga kerja $(81,8 \%)$.

\section{Distribusi Frekuensi Beban Kerja Mental}

Hasil penelitian karakteristik tenaga kerja tentang distribusi frekuensi beban kerja mental di bagian Instalasi CSSD Rumah Sakit Umum Haji Surabaya ditampilkan pada Tabel 4.

Berdasarkan Tabel 4 menunjukkan bahwa dari 11 orang tenaga kerja di instalasi CSSD Rumah Sakit 
Tabel 5. Distribusi Stres Kerja pada Tenaga Kerja Instalasi CSSD Rumah Sakit Umum Haji Surabaya

\begin{tabular}{lcc}
\hline Stress Kerja & Frekuensi (n) & Persentase (\%) \\
\hline Ringan & 5 & 45,455 \\
Sedang & 6 & 54,545 \\
\hline Total & 11 & 100 \\
\hline
\end{tabular}

Umum Haji Surabaya mengalami beban kerja mental sedang sebanyak 7 orang $(63,6 \%)$ sedangkan sisanya mengalami beban kerja mental ringan sebanyak 4 orang $(36,4 \%)$.

\section{Distribusi Frekuensi Stres Kerja}

Hasil penelitian karakteristik tenaga kerja tentang distribusi kejadian stres kerja di bagian Instalasi CSSD Rumah Sakit Umum Haji Surabaya ditampilkan pada Tabel 5.

Berdasarkan Tabel 5 menunjukkan bahwa tenaga kerja instalasi CSSD Rumah Sakit Umum Haji Surabaya mengalami stress kerja sedang sebanyak 6 orang $(54,5 \%)$ dan yang mengalami stres kerja ringan sebanyak 5 orang $(45,5 \%)$.

\section{Hubungan Beban Kerja Mental dengan Stres Kerja}

Hasil gambaran karakteristik tenaga kerja yang dilihat dari hubungan beban kerja mental dengan stres kerja yang dialami oleh tenaga kerja pada bagian Instalasi CSSD Rumah Sakit Umum Haji Surabaya ditampilkan pada tabel 6 .

Berdasarkan Tabel 6 didapatkan bahwa 11 tenaga kerja di bagian Instalasi CSSD memiliki beban kerja mental sedang dan beban kerja mental rendah. Kemudian dari hasil penelitian juga didapatkan bahwa tenaga kerja di instalasi CSSD juga mengalami stres kerja sedang dan stres kerja ringan. Kemudian hasil uji hubungan antara beban kerja mental dengan stres kerja pada tenaga kerja
CSSD Rumah Sakit Umum Haji Surabaya diperoleh bahwa tenaga kerja yang memiliki beban kerja sedang dan tingkat stres kerja sedang sebanyak 6 orang $(85,7 \%)$ dari 7 orang. Sedangkan tenaga kerja yang memiliki beban kerja rendah dengan tingkat stres kerja rendah sebanyak 4 orang ( $100 \%)$ tetapi terdapat 1 orang tenaga kerja dengan beban kerja mental sedang dengan kejadian stres kerja rendah.

Berdasarkan hasil analisis data terhadap beban kerja mental dengan stres kerja didapatkan nilai $p$ value $(0,002)$ yang berarti bahwa nilai $\mathrm{p}<0,05$ maka $h_{\mathrm{o}}$ ditolak artinya ada hubungan antara beban kerja mental dengan stres kerja pada tenaga kerja Instalasi CSSD Rumah Sakit Umum Haji Surabaya. Sedangkan untuk melihat kuat hubungan didapatkan nilai $\mathrm{R}=0,828$ artinya hubungan antara beban kerja mental dengan stres kerja mempunyai hubungan yang kuat searah yang memiliki arti semakin tinggi beban kerja mental yang dialami oleh tenaga kerja maka akan semakin tinggi juga tingkatan yang dialami tenaga kerja di Instalasi CSSD.

\section{PEMBAHASAN}

\section{Umur}

Hasil kelompok umur didapatkan pada saat dilakukan penelitian terhadap tenaga kerja di Instalasi CSSD sebagian besar berumur 40 tahun sampai dengan 44 tahun dengan umur minimal 28 tahun dan maksimal berumur 52 tahun. Dijelaskan dalam undang-undang RI No. 20 tahun 1999 tentang pengesahan ILO mengenai umur minimum untuk diperbolehkan untuk bekerja, bahwasanya usia minimum yang telah ditetapkan untuk dapat bekerja itu tidak boleh kurang dari 15 tahun yang berguna untuk menghapus pekerja anak pada dunia kerja. Menurut Undang-Undang tenaga kerja No.13 tahun 2003 tentang ketenagakerjaan, bahwa penduduk yang dapat dikelompokkan ke dalam tenaga kerja adalah penduduk yang berumur antara 15 tahun hingga 64 tahun. Kelompok umur dalam rentang

Tabel 6. Hubungan Beban Kerja Mental dengan Stres Kerja pada Tenaga Kerja Instalasi CSSD Rumah Sakit Umum Haji Surabaya

\begin{tabular}{|c|c|c|c|c|c|c|c|c|}
\hline \multirow{3}{*}{ Beban kerja mental } & \multicolumn{4}{|c|}{ Stres kerja } & \multirow{2}{*}{\multicolumn{2}{|c|}{ Total }} & \multirow{3}{*}{ Pvalue } & \multirow{3}{*}{$\begin{array}{c}\text { Koefisien } \\
\text { korelasi }\end{array}$} \\
\hline & \multicolumn{2}{|c|}{ Rendah } & \multicolumn{2}{|c|}{ Sedang } & & & & \\
\hline & n & $\%$ & $\mathbf{n}$ & $\%$ & $\mathbf{N}$ & $\%$ & & \\
\hline Rendah & 4 & 36,364 & 0 & 0 & 4 & 100 & \multirow{3}{*}{0,002} & \multirow{3}{*}{0,828} \\
\hline Sedang & 1 & 9,091 & 6 & 54,545 & 7 & 100 & & \\
\hline Total & 5 & 45,455 & 6 & 54,545 & 11 & 100 & & \\
\hline
\end{tabular}


tersebut termasuk dalam kategori kelompok umur produktif. Hal ini menunjukkan bahwa tenaga kerja di instalasi CSSD Rumah Sakit Umum Haji Surabaya termasuk dalam kategori kelompok usia yang produktif.

Umur yang dimiliki seseorang sangat berguna dalam menentukan kontrol seseorang terhadap jenis stressor yang mengganggu sehingga menjadi penyebab kejadian stress yang akan dialami seseorang. Sehingga orang yang berusia dewasa tentu berbeda dengan usia anak-anak dalam hal mengontrol stres. Artinya orang dewasa memiliki toleransi yang baik terhadap kejadian stres.

Menurut penelitian Mochtar dkk (2013) didapatkan bahwa tidak ada hubungan antara umur dengan kejadian stres yang dialami pedagang tradisional pasar daya Kota Makassar. Pendapat sejalan dengan hasil penelitian yang dilakukan oleh Prabowo (2009) bahwa tidak ada hubungan antara umur dengan stres kerja pada tenaga kerja di bagian produksi mebel di Jepara.

\section{Tingkat Pendidikan}

Pendidikan adalah perubahan sikap dan perilaku seseorang atau kelompok dan usaha mendewasakan seseorang melalui upaya pengajaran dan pelatihan. Makin tinggi pendidikan diharapkan makin luas pula pengetahuannya (Notoatmodjo, 2007).

Tingkat pendidikan yang ditempuh oleh individu sangat bervariasi sehingga semakin tinggi pendidikan yang ditempuh seseorang tentunya juga memiliki pengetahuan yang semakin luas serta memiliki cara berpikir yang luas dan mudah dalam menemukan cara yang efisiensi untuk menyelesaikan pekerjaan dengan baik. Pendidikan merupakan suatu sistem terbuka, sehingga memungkinkan adanya pengaruh luar yang menentukan kebenaran atau kesalahan seperti faktor kreativitas. Pendidikan memiliki materi yang luas dan tidak terkait langsung dengan pekerjaannya (Yuwono, 2005).

Berdasarkan hasil penelitian terhadap tenaga kerja di instalasi CSSD didapatkan tingkat pendidikan responden terbanyak pada tingkatan SMA dan sederajat sebanyak $54,5 \%$ responden sedangkan SLTP merupakan tingkatan pendidikan paling sedikit. Penelitian Ratih (2013) menemukan bahwa terdapat hubungan antara tingkat pendidikan dengan stres kerja yang memiliki nilai sedang ditunjukkan dengan nilai correlation coefficient sebesar 0,389. Serta penelitian dari Wijono (2006) yang mengatakan bahwa subjek dengan pendidikan sarjana mengalami stres kerja rendah dibandingkan dengan subjek dengan pendidikan SMU/SMK mengalami stress kerja sedang.

\section{Masa Kerja}

Masa kerja yang baru maupun masa kerja yang lama dapat menjadi pemicu terjadinya stres kerja serta dengan adanya tambahan dari beban kerja yang berat.

Rutinitas kerja yang selalu monoton dapat menimbulkan kebosanan yang disertai dengan lingkungan kerja yang terbatas membuat tenaga kerja menjadi jenuh (Munandar, 2014).

Menurut Mayate (2009) dalam Mochtar (2013) menyebutkan masa kerja memiliki hubungan yang erat dengan kemampuan fisik individu, semakin lama seseorang bekerja maka akan semakin menurun kemampuan fisiknya. Kemampuan fisik akan berangsur-angsur menurun akibat dari kelelahan yang dialami saat bekerja dan dapat diperberat apabila saat melaksanakan pekerjaan yang bervariasi.

Berdasarkan hasil penelitian terhadap tenaga kerja CSSD didapatkan bahwa sebagian besar tenaga kerja sudah memiliki masa kerja yang lebih dari 10 tahun. Tenaga kerja telah melakukan rutinitas pekerjaan monoton dengan waktu yang lama sehingga munculnya rasa bosan serta kejenuhan.

\section{Beban Kerja Mental}

Pekerjaan mempunyai arti penting bagi kemajuan dan peningkatan prestasi, sehingga dapat mencapai kehidupan yang produktif sebagai salah satu tujuan hidup. Setiap pekerjaan tentunya akan memberikan beban kepada tenaga kerja atau manusia baik itu secara fisik maupun beban secara mental, dari sudut pandang ergonomi, setiap beban kerja yang diterima oleh seseorang harus sesuai atau seimbang baik terhadap kemampuan fisik, kemampuan kognitif maupun keterbatasan manusia yang menerima beban tersebut. Beban kerja fisik adalah beban kerja yang diterima dari pekerjaan yang memerlukan energi fisik seperti kegiatan mengangkat, mendorong, mengangkut, sedangkan untuk beban kerja mental merupakan selisih antara tuntutan antara beban kerja dari suatu tugas dengan kapasitas maksimum seseorang dalam kondisi termotivasi (Rauf dalam Mutia, 2014).

Pengukuran beban kerja mental mengunakan metode NASA-TLX diwakili 6 indikator dengan mental demand yang meliputi kegiatan berpikir, memutuskan, mengingat, dan melihat pekerjaan 
tersebut kompleks atau tidak. Physical demand yang meliputi kegiatan mendorong, menari, memutar, dan mengontrol suatu pekerjaan. Temporal demand meliputi berapa lama waktu yang digunakan serta seberapa cepat suatu pekerjaan dilaksanakan. Own performance yang meliputi kegiatan seberapa sukses dalam berpikir saat menyelesaikan suatu pekerjaan. Effort dengan kegiatan seberapa keras usah yang dilakukan untuk bekerja. Frustration on level adalah berdasarkan rasa aman yang dirasakan saat melaksanakan pekerjaan apakah pekerja menikmati pekerjaannya.

Hasil penelitian didapatkan dari proses penjumlahan semua indikator dan dikalikan dengan nilai bobot yang diberikan tenaga kerja di instalasi CSSD Rumah Sakit Umum Haji Surabaya menunjukkan bahwa dari 11 tenaga kerja di instalasi CSSD terdapat $63,6 \%$ tenaga kerja yang mengalami beban kerja mental sedang, yaitu sebanyak 7 tenaga kerja. Sedangkan untuk tenaga kerja lainnya mengalami beban kerja mental ringan sebanyak 4 tenaga kerja $(36,4 \%)$.

Beban kerja mental yang lebih besar daripada kemampuan tubuh maka akan terjadi rasa tidak nyaman (tahap awal), kelelahan (overstress), cedera, kecelakaan, rasa sakit, penyakit dan produktivitas menurun (tahap akhir). Sebaliknya, jika beban kerja lebih kecil dari kemampuan tubuh, maka akan terjadi (understress), kejenuhan, kebosanan, kelesuan, kurang produktif, dan sakit (Santoso, 2004). Hal ini menunjukkan bahwa semakin tinggi beban kerja mental pada tenaga kerja Instalasi CSSD, maka semakin besar tingkat risiko stres kerja yang dialami tenaga kerja instalasi CSSD Rumah Sakit Umum Haji Surabaya.

\section{Stres Kerja}

Stres kerja dapat diartikan sebagai respons adaptif yang dirasakan oleh tenaga kerja yang berasal dari interaksi antara kondisi kerja dengan sifatsifat kerja yang dapat mengganggu fungsi mental, fisik, dan kimiawi dalam tubuh jika tidak ditanggapi dengan positif, tetapi stres juga memiliki nilai positif sebagai pemacu semangat dalam menyelesaikan pekerjaan ataupun tugas-tugas dengan baik, benar, dan penuh kreativitas (Anoraga, 2009).

Menurut Munandar (2014) juga menyatakan bahwa stres tidak selalu berdampak buruk bagi tenaga kerja dalam kehidupan. Stres dikategorikan menjadi 2 kelompok yaitu eustress yang memiliki arti sebagai kekuatan positif sedangkan distress yang bersifat destruktif. Stres juga diperlukan untuk menghasilkan prestasi dan produktivitas yang tinggi. Semakin tinggi dorongan untuk memiliki prestasi, maka semakin tinggi juga produktivitas dan efisiensinya. Demikian juga sebaliknya stres kerja dapat menimbulkan efek negatif. Stress dapat berkembang menjadi sakit baik fisik ataupun mental sehingga tidak dapat bekerja dengan baik.

Stres kerja adalah perasaan tertekan yang dialami tenaga kerja dalam menghadapi pekerjaannya. Pengukuran stress kerja dilakukan dengan menggunakan kuesioner penilaian stres akibat kerja dari Health and Safety Executive (HSE) dengan metode skoring. Penilaian kuesioner dilakukan menggunakan 5 skala likert (tidak pernah, jarang, agak sering, sering, dan selalu) dari 35 daftar pertanyaan. Tenaga kerja di instalasi CSSD diminta untuk mengisi kuesioner yang telah disiapkan.

Berdasarkan hasil yang telah didapatkan terdapat 5 orang tenaga kerja yang mengalami stres ringan, sedangkan 6 orang tenaga kerja mengalami stres sedang, dan tidak ada tenaga kerja yang mengalami stres tinggi maupun stres sangat tinggi. Pada stres kerja ringan belum diperlukan kontrol untuk perbaikan, namun untuk stres kerja sedang memungkinkan untuk dilakukannya kontrol terhadap gejala stres di kemudian hari.

Stres pada pekerjaan dapat dicegah dan dapat dihadapi dengan manajemen stres. Manajemen stres bertujuan untuk mencegah berkembangnya stres jangka pendek menjadi stres jangka panjang atau stres kronis. Hal ini dapat dilakukan dengan cara mengubah faktor-faktor di lingkungan kerja sehingga tidak menimbulkan stres dan mengubah faktor-faktor dalam individu agar tidak cepat merasakan situasi stres dan dapat bertahan lebih lama dalam situasi penuh stres, sehingga tidak sampai menimbulkan gejala-gejala terjadinya stres, dan dapat mempertahankan status kesehatan.

\section{Hubungan Beban Kerja Mental dengan Stres Kerja}

Menurut Chen dkk (2010) mengatakan bahwa beban kerja yang berat yang dialami dalam jangka panjang akan mempengaruhi kesehatan tenaga kerja baik fisik dan mental, sehingga adanya respon dari situasi di sekitar tempat kerja menjadi bahaya atau ancaman seperti rasa takut, cemas, rasa bersalah, marah, sedih, putus asa dan stres.

Berdasarkan hasil penelitian di Rumah Sakit Umum Haji Surabaya pada instalasi CSSD didapatkan data bahwa adanya hubungan antara beban kerja mental dengan stres kerja Berdasarkan 
uji korelasi spearman yang telah dilakukan, didapatkan hasil signifikansi sebesar 0,002 , nilai ini lebih kecil dari nilai $\alpha 0,05$ yang berarti bahwa beban kerja mental dengan stres kerja tenaga CSSD memiliki hubungan yang bermakna. Dari hasil yang didapatkan bahwa tenaga kerja CSSD memiliki beban kerja mental sedang sebanyak $63,6 \%$ dan tenaga kerja yang mengalami stres kerja sedang sebanyak $54,5 \%$.

Adanya hubungan antara beban kerja mental dengan stres kerja yang dialami oleh tenaga kerja instalasi CSSD Rumah Sakit Umum Haji karena tenaga kerja telah ditargetkan dalam menyelesaikan pekerjaan sesuai waktu yang ditentukan. Selain itu pekerjaan dari tenaga kerja juga melakukan pekerjaan yang berulang setiap harinya. Selain itu apabila terjadi peningkatan pasien yang datang serta penggunaan alat steril untuk melaksanakan operasi tentunya membutuhkan alat steril yang cepat dipersiapkan.

Hasil penelitian ini sejalan dengan penelitian yang dilakukan oleh Novayanti (2012) yang menyatakan bahwa terdapat hubungan antara tuntutan tugas beban kerja dengan stress kerja. Penelitian Emilda (2014) menyatakan bahwa terdapat hubungan yang bermakna antara beban kerja mental dengan stres kerja yang dilakukan pada perawat instalasi IGD. Selain itu, penelitian yang dilakukan oleh Situngkir (2004) juga menyatakan bahwa ada hubungan yang signifikan antara tuntutan fisik/lingkungan kerja dengan kejadian stres kerja.

Hasil penelitian Shah, dkk (2011) menjelaskan bahwa beban kerja memiliki hubungan yang signifikan terhadap performa pekerja. Beban kerja yang tinggi dipengaruhi kemampuan pekerja. Prabawati (2012) juga menyatakan bahwa beban kerja mental memiliki hubungan dengan kejadian stres dibuktikan dengan penelitiannya pada perawat di Rumah Sakit dengan hasil $p=0,027$ yang berarti terdapat hubungan yang signifikan antara keduanya dengan kekuatan korelasi 0,556 yang menunjukkan korelasi yang kuat antar variabel.

Menurut Munandar (2014), pada saat tertentu, kondisi kerja dapat menghasilkan prestasi kerja yang optimal. Selain dampaknya terhadap prestasi kerja, kondisi seperti tuntutan kerja fisik/lingkungan fisik juga memiliki dampak terhadap kesehatan mental dan keselamatan kerja seseorang. Tuntutan kerja fisik ini mempunyai pengaruh terhadap kondisi psikologis pekerja, sehingga dapat memicu terjadinya stres. Hal ini diakibatkan karena terjadinya ketidakseimbangan psikologis dalam diri pekerja sehingga sulit untuk berkonsentrasi dengan baik.

Santoso (2004) menyatakan bahwa setiap beban kerja mental harus disesuaikan dengan kemampuan tubuh seseorang. Apabila beban kerja mental lebih besar daripada kemampuan tubuh maka akan terjadi rasa tidak nyaman, kelelahan, kecelakaan, cidera, rasa sakit, penyakit, stres dan produktivitas menurun. Faktor-faktor lain yang mempengaruhi beban kerja mental seseorang dalam suatu pekerjaan antara lain adalah jenis pekerjaan, situasi pekerjaan, waktu respons, waktu penyelesaian yang tersedia dan faktor individu seperti: tingkat motivasi, keahlian, kelelahan, kejenuhan, serta toleransi performansi yang diijinkan (Risma, 2010).

Dampak buruk yang disebabkan oleh beban kerja mental, salah satunya adalah stres kerja. Sehingga tenaga dapat melakukan pencegahan seperti melaksanakan olah raga ringan sebelum melaksanakan pekerjaan atau disela-sela pekerjaan seperti menggerakkan tangan dan kaki saat duduk. Karena, dengan olah raga dapat membuat aliran darah dalam tubuh menjadi lancar sehingga pikiran menjadi lebih segar dan ketegangan otot menjadi rileks dan mengurangi beban kerja yang di alami serta mengurangi tekanan dan stres akibat pekerjaan. Tenaga kerja sebaiknya memanfaatkan waktu istirahat dengan sangat baik untuk beristirahat sehingga untuk melanjutkan pekerjaan selanjutnya tidak merasakan beban dari pekerjaan sebelumnya.

\section{SIMPULAN}

Berdasarkan hasil penelitian yang dilakukan di Rumah Sakit Umum Haji Surabaya didapatkan hasil dari karakteristik tenaga kerja pada bagian instalasi CSSD pertama adalah tentang kelompok umur yang bekerja paling banyak adalah terdiri dari kelompok umur 40-44 tahun dan termasuk di dalam kelompok umur yang produktif. Kedua adalah tentang tingkat pendidikan yang ditempuh tenaga kerja dan yang paling banyak berada pada tingkatan SMA dan sederajat. Ketiga adalah tentang masa kerja dari tenaga kerja instalasi CSSD yang dapat dikatakan sebagai tenaga kerja yang berpengalaman karena memiliki masa kerja yang lebih dari 10 tahun dan hanya 2 orang yang memiliki masa kerja kurang dari 10 tahun.

Sebanyak $7(63,6 \%)$ tenaga kerja dari 11 tenaga kerja di Instalasi CSSD Rumah Sakit Umum Haji Surabaya mengalami beban kerja mental sedang 
dan tingkatan stres kerja yang dialami oleh tenaga kerja Instalasi CSSD Rumah Sakit Umum Haji Surabaya adalah tingkat stres kerja sedang sebanyak 6 tenaga kerja $(54,5 \%)$ dari 11 orang tenaga kerja. Ada hubungan antara beban kerja mental dengan stres kerja pada tenaga kerja Instalasi CSSD Rumah Sakit Umum Haji Surabaya dengan kuat hubungan searah yang memiliki arti semakin tinggi beban kerja yang dialami tenaga kerja maka akan semakin tinggi tingkatan stres yang dialami oleh tenaga kerja. Saran pada penelitian ini adalah sebaiknya tenaga kerja beristirahat yang cukup untuk menjaga keseimbangan tubuh dalam melakukan aktivitas kerja.

\section{DAFTAR PUSTAKA}

Anoraga, P. 2009. Manajemen Bisnis. Jakarta: PT Rineka Cipta.

Chen, T.H., Wu, K.H., Lin, W.J., Horna, W.I., and Shied, C.J. 2010. Incorporating Workload and Performance Levels into Work Situation Analysis of Employees with Application to a Taiwanese Hotel Chain. American Journal of Applied Sciences 7 (5) 692-697.

Emilda, S. 2014. Analisis Pengaruh Beban Kerja Mental terhadap Stres Kerja Perawat Instalasi Gawat Darurat (Studi di Rumah Sakit Umum Haji Surabaya). Skripsi. Surabaya: Universitas Airlangga.

Harrington, J.M \& Gill, F.S. 2005. Buku Saku Kesehatan Kerja. Jakarta: EGC.

Kementerian Kesehatan Republik Indonesia. 2012. Profil Kesehatan Indonesia.

Mangkunegara, A.P. 2011. Manajemen Sumber Daya Manusia Perusahaan. Bandung: PT Remaja Rosdakarya Offset.

Munandar, A.S. 2014. Psikologi Industri dan Organisasi. Jakarta: UI Press.

Mutia, M, 2014. Pengukuran beban kerja fisiologis dan psikologis pada operator pemetikan teh dan operator produksi teh hijau di PT Mitra Kerinci. Jurnal Optimasi Sistem Industri, Vol. 13 No. 1, 503-517.

Mochtar, S.M, Muis, M, Rahim, M.R. 2013. Faktor yang berhubungan dengan stress kerja pada pedagang tradisional pasar Daya Kota Makassar tahun 2013. Skripsi. Makassar: Universitas Hasanuddin.

Notoatmodjo, S. 2007. Promosi Kesehatan dan Ilmu Perilaku. Jakarta: Rineka Cipta.

Novayanti, R. 2012. Analisis Faktor-Faktor yang Berhubungan dengan Stres Kerja pada Guru Honorer SMA di Jakarta Timur tahun 2012. Skripsi. Depok: Universitas Indonesia.

Prabawati, R. 2012. Hubungan Beban Kerja Mental dengan Stres Program Studi Diploma IV Keselamatan dan Kesehatan Kerja Pada Perawat bagian Rawat Inap RSJD Dr. R. Soedjarwadi Klaten. Skripsi. Semarang: Universitas Negeri Semarang.

Prabowo. 2009. Faktor yang berhubungan dengan kejadian stress kerja pada bagian produksi mebel PT. Chia Jian Indonesia furniture di Wadelan Jepara Tahun 2009. Skripsi. Semarang: Universitas Negeri Semarang.

Ratih, Y.F.E., Suwandi, T. 2013. Analisis Hubungan Antara Faktor Individu dan Beban Kerja Fisik dengan Stres kerja di bagian Produksi PT. X Surabaya. The Indonesian Journal of Occupational safety and Health, Vol. 2, No. 2, p. 97-105.

Risma, A. S. 2010. Analisis Beban Kerja Mental dengan metode NASA-TLX. Jurnal Teknologi, Vol. 3 No. 1, 53-60.

Santoso, G. 2004. Manajemen Keselamatan dan Kesehatan Kerja. Jakarta: Prestasi Pustaka.

Shah, S.S.H., Jaffari, A.R., Aziz, J., Ejaz, W., Ul-Haq, I., Raza, S.N., Workload and Performance of Employees. 2011. Interdisciplinary Journal of Contemporary Research in Business, Vol. 3 No. 5.

Tarwaka. 2010. Ergonomi Industri. Surakarta: Harapan Press.

Undang-Undang Republik Indonesia No. 13 Tahun 2003 tentang Ketenagakerjaan.

Undang-Undang Republik Indonesia No. 20 Tahun 1999 Tentang Pengesahan ILO Convention no. 138 Concerning Minimum Age for Admission to Employment (Konvensi ILO Mengenai Usia Minimum Untuk Diperbolehkan Bekerja).

Undang-Undang Republik Indonesia No. 44 Tahun 2009 tentang Rumah Sakit.

Wijono, J. 2006. Filsafat dan Etika Penelitian Sosial dan Kesehatan. Surabaya: Duta Prima Airlangga.

Yuwono, I., Suhariadi., Fendy. 2005. Psikologi Industri dan Organisasi. Surabaya: Fakultas Psikologi Universitas Airlangga. 